\title{
PELATIHAN DAN PENDAMPINGAN BANTUAN HIDUP DASAR DAN PERTOLONGAN PERTAMA PADA ANGGOTA POKDARWIS DI DESA SAMBANGAN
}

\author{
Putu Adi Suputra ${ }^{1}$, Ni Made Sri Dewi Lestari ${ }^{2}$, Gede Surya Dinata ${ }^{3}$, \\ Ni Nyoman Mestri Agustini ${ }^{4}$ \\ 1,2,3,4 Fakultas Kedokteran, Universitas Pendidikan Ganesha \\ e-mail :dr.adisuputra@gmail.com, sri.dewi@undiksha.ac.id, \\ surya.dinata@undiksha.ac.id, nyoman.mestri@undiksha.ac.id
}

\begin{abstract}
Abstrak
Tujuan utama kegiatan pengabdian masyarakat ini adalah untuk meningkatkan pengetahuan dan pemahaman tentang manfaat BHD dan penanganan cedera, serta meningkatkan keterampilan anggota Pokdarwis Sambangan dalam melakukan BHD dan perrtolongan pertama pada cedera. Metode pelaksanaan program P2M adalah penyuluhan, pelatihan dan pendampingan. Hasil menunjukkan terdapat peningkatan pengetahuan peserta dimana pada saat pre-test hanya $45 \%$ persen peserta yang tahu dan memahami tentang BHD dan pertolongan pertama pada cedera. Setelah dilaksanakan pelatihan dan diberikan post-test, hampir $80 \%$ peserta memahami tentang BHD dan pertolongan pertama pada cedera. Pelatihan ini juga membuat antusiasme peserta meningkat untuk mengetahui tentang BHD dilihat dari banyaknya pertanyaan dari peserta dan keaktifan dalam melakukan demonstrasi tentang BHD.
\end{abstract}

Kata kunci: bantuan hidup dasar, pertolongan pertama pada cedera, pokdarwis sambangan

\begin{abstract}
The main objective of this community service activity is to increase knowledge and understanding of the benefits of BLS and first aid for injuries, as well as improve the skills of Pokdarwis Sambangan members in performing BLS and first aid for injuries. The method of implementing the P2M program is counseling, training and mentoring. The results showed that there was an increase in participants' knowledge where at the time of the pretest only $45 \%$ percent of participants knew and understood about BLS and first aid in injuries. After training and being given a post test, nearly $80 \%$ of the participants understood BLS and first aid for injuries. This training also increased the participants' enthusiasm to know about BLS, seen from the many questions from the participants and their activeness in conducting demonstrations about BLS.
\end{abstract}

Keywords : basic life support, first aid, pokdarwis sambangan

\section{PENDAHULUAN}

Pertolongan pertama pada kecelakaan merupakan aspek penting pada kehidupan sehari-hari, baik itu dirumah,dijalan, disekolah, maupun di kantor, karena kejadian yang merupakan darurat perlu segera ditangani di tempat kejadian. Sesuai dengan definisi dari pertolongan pertama adalah usaha-usaha untuk menangani korban dengan segera di tempat kejadian. Prinsip-prinsip pertolongan pertama adalah tindakan yang dilakukan segera, mempertahankan hidup korban, mengurangi penderitaan, mencegah pengotoran luka dan penderitaan lanjutan serta merujuk korban ke tempat pelayanan kesehatan terdekat. Prinsip-prinsip pertolongan pertama ini sangat dianggap perlu bagi semua lapisan masyarakat, karena dengan hal tersebut kita dapat membantu orang atau korban sampai benar-benar mendapat perawatan medis 
profesional. Pertolongan pertama bisa dilakukan oleh baik itu masyarakat umum ataupun siswa, sampai pertolongan medis profesional tiba untuk menangani korban (Saubers,Nadine, 2008)

Sambangan, sebuah desa yang posisinya di atas bukit hijau di Kecamatan Sukasada yang jaraknya $6 \mathrm{~km}$ dari Kota Singaraja. Jumlah penduduknya berjumlah 5986. Desa Sambangan letaknya berdampingan dengan Desa Ambengan yang hanya di batasi oleh sebuah jurang yang cukup lebar, karena itu secara geografis juga tidak jauh berbeda diantara kedua desa tersebut. Disamping dikelilingi oleh hamparan sawah (rice terrace) yang mempesona, desa ini juga memiliki potensi air terjun serta sebuah bendungan yang sangat cocok untuk wisata alam seperti trekking dan juga meditasi, karena banyak memiliki tempat yang menawarkan ketenangan jiwa. Bagi mereka yang ingin mengenang masa lalu dengan mandi di sungai, desa ini memiliki banyak kolamkolam alami disepanjang sungai dengan airnya yang bersih. Di desa Sambangan memiliki 9 objek dan daya tarik wisata alam yaitu Air terjun Aling-aling, Air Terjun Kroya, Air Terjun Kembar, Air Terjun Pucuk, Air Terjun Batu Barak, Air Terjun Cemara, Air Terjun Canging, Air Terjun Dedari dan Teracering.

Berdasarkan observasi awal dan wawancara dengan salah satu anggota Pokdarwis di daerah Sambangan, yang merupakan guide trekking yang bernama Ida Bagus Putu Mustana,dikatakan bahwa pernah dilakukan pelatihan oleh PMI tentang penanganan cedera pada pelaku pariwisata, akan tetapi hanya diberikan tentang penanganan cedera saja seperti mengangkat korban, penanganan patah tulang, luka lecet dan luka terbuka. Belum pernah dilakukan pelatihan tentang bantuan hidup dasar dan penanganan cedera secara komprehensif. Salah seorang karyawan di Krisna Adventure Sambangan juga menjelaskan bahwa ditempat kerjanya belum pernah diadakan pelatihan tentang bantuan hidup dasar dan pertolongan pertama. Bantuan hidup dasar adalah tindakan yang bisa diberikan oleh tenaga kesehatan atau orang awam yang sudah terlatih untuk menolong pasien henti jantung, gagal nafas, dan obstruksi jalan napas (Stella et al, 2020). Padahal keterampilan ini sangat diperlukan dalam memberikan pertolongan pertama pada wisatawan bila ada yang mengalami cedera ataupun henti jantung. Mereka sangat mengharapkan diadakan pelatihan tentang bantuan hidup dasar dan pertolongan pertama, sebagai tambahan ketrampilan apabila terjadi kegawat daruratan.

Para pemadu wisata di Sambangan berharap adanya pelatihan yang lebih lengkap seperti pelatihan bantuan hidup dasar yang diberikan kepada mereka sebagai bekal awal bila ada kecelakaan atau kejadian sakit yang menimpa wisatawan saat mereka bekerja. Program pengabdian masyarakat ini merupakan program yang berasal dari DIPA Universitas yang diharapkan dapat berlangsung rutin, sehingga ketrampilan dari pemandu wisata dapat ditingkatkan. Berdasarkan permasalahan tersebut, diberikan solusi dengan mengadakan pelatihan dan pendampingan bantuan hidup dasar dan pertolongan pertama pada Pokdarwis di desa Sambangan.

\section{METODE}

Pelaksanaan P2M ini berupa kegiatan pelatihan dan pendampingan untuk tujuan monitoring dan evaluasi peningkatan pengetahuan dan skill khalayak sasaran. Kegiatan pelatihan dan pedampingan dilaksanakan dengan langkah sebagai berikut :

(1) Metode ceramah yaitu untuk menyampaikan materi-materi tentang BHD

(2) Metode praktek atau demonstrasi yaitu untuk mendemonstrasikan bagaimana menangani korban di tempat kejadian secara sigap dan cepat.

(3) Metode diskusi yaitu untuk mendiskusikan kembali materi yang telah disampaikan sehingga terjadi interaksi timbal balik antara para peserta dengan peserta dan antara peserta dengan pelatih.

(4) Metode pelatihan dengan pendekatan modelling yaitu dengan penerapan metode pelatihan ini para peserta 
dapat secara langsung mengikuti pelatihan tentang BHD dengan memakai alat peraga dan model.

(5) Metode pendampingan yaitu melalukan pendampingan pada pokdarwis, akan dilakukan kunjungan untuk tindak lanjut kegiatan untuk memperdalam pemahaman dan keterampilan pokdarwis Desa Sambangan tentang BHD dan pertolongan pertama pada cedera.

\section{HASIL DAN PEMBAHASAN}

Observasi P2M ini dilaksanakan tanggal 11 januari 2020, sedangkan koordinasi dilaksanakan tanggal 18 juli 2020. Pelaksanaan P2M ini dilakukan dengan metode pendampingan dan pelatihan. Pelatihan dilaksanakan pada hari Jumat tanggal 24 Juli 2020 mulai pukul 09.00-13.00 WITA, bertempat di balai desa Desa Sambangan. Peserta berjumlah 20 orang yang berasal dari anggota Pokdarwis Desa Sambangan. Pemateri dalam pelatihan ini berjumlah 1 orang yaitu Dr.dr. I Ketut Indra Purnomo, M.Kes. Materi yang disampaikan adalah materi yang erat kaitannya dengan kejadian kecelakaan yang sering dialami oleh wisatawan, sehingga para pokdarwis memiliki pengetahuan, wawasan dan pengalaman terkait bantuan hidup dasar dan pertolongan pertama pada cedera yang di temukan pada para wisatawan.

Pendampingan selanjutnya sudah dilaksanakan pada bulan September. Pendampingan ini dilakukan sebagai tindak lanjut kegiatan untuk memperdalam pemahaman dan keterampilan pokdarwis Desa Sambangan tentang BHD dan pertolongan pertama pada cedera. Peningkatan pengetahuan pada pokdarwis dilihat dari peningkatan kemampuan yang di tes dengan pre- test dan post-test. Pada saat pre-test hanya $45 \%$ persen peserta yang tahu dan memahami tentang BHD dan pertolongan pertma. Setelah dilaksanakan pelatihan dan diberikan post-test, hampir $80 \%$ peserta memahami tentang BHD dan pertolongan pertama pada cedera

Peningkatan pengetahuan pada peserta dilihat dari peningkatan kemampuan peserta dengan pre-test dan post-test. Pada saat pre-test hanya $45 \%$ persen peserta yang tahu dan memahami tentang BHD dan pertolongan pertama pada cedera. Setelah dilaksanakan pelatihan dan diberikan post-test, hampir $80 \%$ peserta memahami tentang BHD dan pertolongan pertama pada cedera. Pelatihan ini juga membuat antusiasme peserta meningkat untuk mengetahui tentang BHD. Ini dilihat dari banyaknya pertanyaan dari peserta dan keaktian dalam melakukan demonstrasi tentang BHD. Perencanaan program selanjutnya adalah mengadakan program pelatihan dan pendampingan rutin, sehingga dapat meningkatkan kualitas ketrampilan dari Pokdarwis tentang BHD dan pertolongan pertama. Untuk selanjutnya akan dibuat buku saku tentang BHD dan pertolongan pertama yang di khususkan untuk Pokdarwis. Hasil ini sesuai dengan pengabdian yang dilakukan oleh Chalil (2018), bahwa terjadi peningkatan pengetahuan dan ketrampilan tentang BHD pada kelompok lifeguard di lokasi wisata pantai cermin,

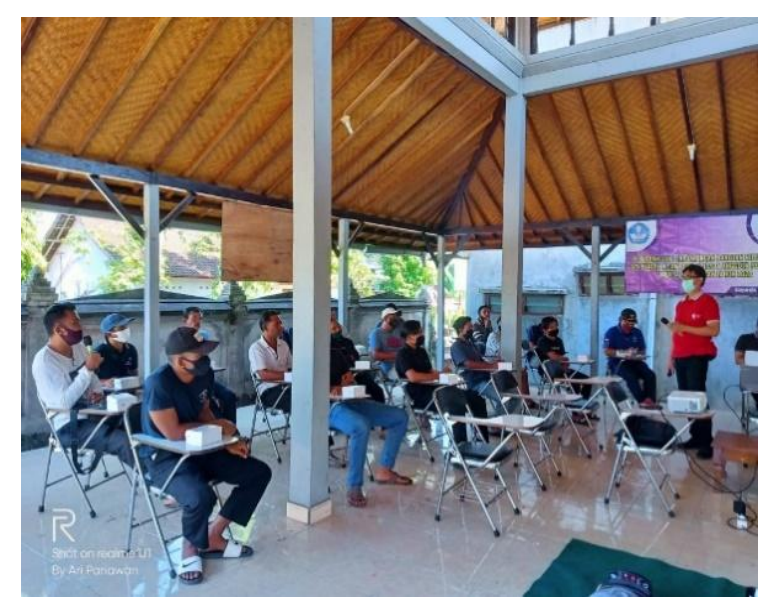

Gambar 1. Pemaparan Materi Pelatihan 


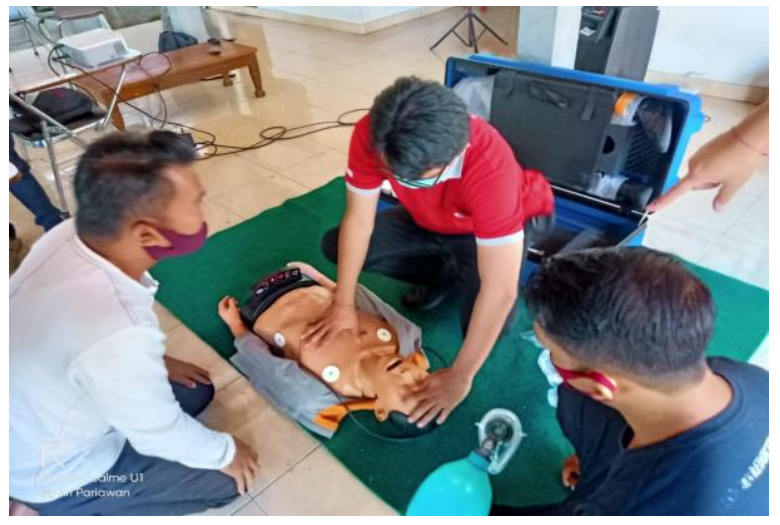

Gambar 2. Praktek dan pelatihan BHD

\section{KESIMPULAN}

Berdasarkan hasil pelaksanaan kegiatan pengabdian pada masyarakat yang berupa Pelatihan dan Pendampingan Bantuan Hidup Dasar dan Pertolongan Pertama pada anggota Pokdarwis di Desa SambanganTahun 2020 dapat ditarik kesimpulan bahwa pelaksanaan kegiatan P2M tersebut telah berjalan dengan baik yang dapat diketahui dari hasil yaitu meningkatnya pemahaman dan pengetahuan peserta tentang BHD. Hal ini dapat dilihat dari hasil pos-test yang meningkat sampai 80 persen peserta memahami tentang BHD dan pertolongan pertama pada cedera.

\section{DAFTAR PUSTAKA}

Anonim, 2002, First Aid, Headquarters Department of The Army, The Navy, and The Air Force, Texas, USA

Chalil, M.J.A dan Hamdani, I., 2018, Pendidikan dan Pelatihan Bantuan Hidup Dasar pada Komunitas Lifeguard di Lokasi Wisata Pantai Cermin, Jurnal Prodikmas, Volume 3
No1,DOI:https://doi.org/10.30596/jp. v3i1.2612

Saubers, Nadine, 2008, The Everything First Aid Book, Adams Media, Massachusetts, USA

Wyatt, J.P et al, 2005, Oxford Handbook of Accident and Emergency Medicine, Oxford University Press

Armstrong, Vivien et al, 2002, Home Emergency Guide, DK Publishing, New York

Stella, M.A, et al, 2020, The Effect Of Basic Life Support (Bls) Training In The Knowledge And Skill Level Of Community In Sidodadi Village, Lawang, Indonesia, Indonesian Journal Of Anesthesiology And Reanimation, Volume 2 Number 1, January 2020 : 8-12

Susilo, Juliati dkk, 2008, Pertolongan Pertama Palang Merah Remaja Madya, Palang Merah Indonesia Pusat, Jakarta

Anonim, 2010, "Pros and Cons of First Aid Training?", Canadian Medical Association Journal, vol. 182, no. 12.

Dean, $\mathrm{R}$ and Mulligan, J, 2009, “ Management of Procedures and Reactions Following First Aid" Nursing Standard, vol. 24, no. 11, pp. 35-39

"First Aid", (2010, October 26- last update), Available at :http://en.wikipedia.org/wiki/First_aid (Accessed : 2013, August 30)

"Palang Merah Indonesia", (2008-last update), Available at :http://www.pmi.or.id/ina (Accessed : 2013, August 30)

Zamroni, Dian et al, 2019, Buku Ajar Kursus Bantuan Hidup Jantung Dasar, Penerbit PERKI, Jakarta 